\title{
Implementation Program Child Friendly City at Langkat Regency
}

\author{
Asima Yanty Siahaan \\ Department of Public Administration \\ University of Sumatera Utara \\ Medan, Indonesia \\ asimayantysiahaan@gmail.com
}

\author{
Rizki Fadly \\ Department of Public Administration \\ University of Sumatera Utara \\ Medan, Indonesia \\ rizki.fadly94@gmail.com
}

\begin{abstract}
Development in a country is not only the responsibility of the government alone but every component of human resources that live and thrive in the region. The development concept is a visionary who will give birth to some of the policies that will address and resolve any issues that exist among the people in detail and depth. Program child friendly is a development system regency/municipality that integrates the commitment and resources of government, public and business are planned thoroughly and sustainable policies, programs, and activities for the fulfillment of children's rights. This research aims to determine how the application of child friendly city policy in Langkat regency. The method used in this research is a descriptive method with a qualitative approach. Implementation of the policy can be concluded that the child friendly city in Langkat has been good, just need to do advocacy and socialization harder to the ranks regional work unit (SKPD) Langkat district government, the public and the business community. Then need to be improved in terms of the budget so that the policy can be implemented optimally.
\end{abstract}

Keywords-public policy, coordination, children right, city eligible children introduction

\section{INTRODUCTION}

Children are the next generation of a nation that has a strategic position in the development and development of human tapping. Especially in facing the era of Asian economic community (MEA), children as a young generation become one of the nation's pedestals that will face global problems. Creating a proper life arrangement for children is important to create potential and reliable human resources in responding to all challenges of its time.

Much of Indonesia's progress has been made in advancing the protection, respect, and fulfillment of children's rights as set out by the Government of Indonesia's report on the implementation of the Convention on the Rights of the Child to the UN rights committee of the United Nations in Geneva. According to the government, more children are in school than in previous years, more children are becoming actively involved in decisions about their lives, and have also established important legislation that protects children.

However, there is currently inequality in implementing children's rights in all districts/cities (PKPA, 2013). The bright future for children is a mere conceptualization, and districts are still not child-centered either in their policies or in the preparation of spatial and infrastructure, in many areas and in almost all sectors of children's rights still unfulfilled and well-protected. Violence and exploitation of children are still common. On the other hand, Indonesian cities, currently growing at an average annual rate of $4.4 \%$ (UNICEF, 2007), result from uncontrolled population growth and rural-to-urban migration. As a result, the provision of basic services, housing, education, health and job opportunities is also increasingly difficult. The impact is that the city/district is full of exploited children, and violence against children takes place in all spaces, at home, in schools, on the streets, and in spaces others.

Responding to social problems especially experienced by children, an idea came from a number of child observers to create a friendly or decent district or city. The idea of the Child Friendly City begins with research on "Children Perception of the Environment" by Kevin Lynch (Architect of the Massachusetts Institute of Technology) in 4 cities: Melbourne, Warsaw, Salta and Mexico City 1971-1975. The results show that the best urban environment for children is those with strong physical and social community.

Communities that have clear and decisive rules, which provide opportunities for children, and educational facilities that provide opportunities for children to learn and investigate their environment and world.Through the City Summit, Unicef and Un-Habitat introduced the Child-Friendly City Initiative, especially touching the city's children. Especially the poor and marginalized of basic services and protection to guarantee their basic rights. At the meeting, they also recommended to the mayors of the world to develop an action plan for their city to be a friendly city and protect the rights of children, and then promote the role of children as change actors in their city decision-making process, especially in the process of implementing and evaluating city government policies.

These agreements have become the National Government of Indonesia's agenda. To overcome the problems of children in Indonesia, especially at the district/city level, the development of child friendly city, this is one of the best solutions. The policy is stipulated in the Regulation of the Minister of Women Empowerment and Child Protection (KPP and PA RI) Number 02 The year 2009 regarding the policy of District or City of Children Eligible.

North Sumatera is a province that also develops the District/City Decent of Children policy by appointing several districts/municipalities to serve as a pilot area in applying 
regency/city decent children policy. One of the regions that have implemented child friendly city policy is Langkat Regency. Since 2010, Langkat regency has become one of the 8 regencies/cities in North Sumatera as the development area of the Regency/city for children by the Governor of Sumatera Province. With the issuance of Langkat District Regulation No. 3 of 2013 on the implementation of child protection strengthens the seriousness of Langkat Regency in integrating local government policies in accordance with the rights of children.

\section{RESEARCH METHODOLOGY}

The method used in this research is descriptive research method with a qualitative approach. This research was conducted in several places in Langkat Regency and doing research at various institutions such as the government of Langkat Regency, Children Forum, NGOs, and society.Primary data collection techniques through various ways which one Interview. Secondary data collection method is data that is not directly from the research object consisting of literature research and documentation study. The data analysis during the field according to Miles and Huberman in (Sugiono 2012) is data reduction, data presentation, and drawing conclusions.

\section{RESULT AND DISCUSSION}

Agustino in Public Policy Basics (2008) explains that the approach model formulated by Metter and Horn is called a model of the policy implementation. There are six variables according to Metter and Horm, which affect public policy performance. The six variables will be the basis of the research discussion. The policy implementation variables, namely:

\section{A. Size and Purpose of The Policy}

The Decent Regency / City Development Policy (child friendly city) is Indonesia's participation in the world's commitment to creating a Children's Worthy World. The Regency/municipality of children is an expression of the international agreement on the need for a world fit for children based on the UN Convention on the Rights of the Child in 1989. Referring to the international agreement and as the implementation of Law No. 23 of 2002 on Child Protection, the state is committed to pursuing the realization of childworthy Indonesia through the development of child friendly city in all districts/cities throughout Indonesia.

From 2012 until now the development of decent children's district policy is being encouraged in Langkat district, through the PPKB and PPA offices of Langkat Regency as the leading sector and child friendly city task force team which is mandated by Langkat Regent through its decision letter. It is the basis of child friendly city policy implementation in Langkat regency besides the ministerial regulation no 13 in 2011. then carried out coaching in the form of child friendly city seminar attended by officials regional work unit (SKPD) in Langkat Regency, strengthening of facilitator team child friendly city Langkat Regency, as well as there, are coaching activities at village / kelurahan worthy of children from 2012 until now.

The basic implementation of child friendly city in Langkat Regency is also related to Law No. 35 of 2014 on child protection, on the basis of that also Langkat regency government issued local regulation Langkat number 03 the year 2013 about child protection In Langkat itself there is no regional regulation that focuses on the policy Decent Regency Children are only local regulations that are assembled with child protection. The steps taken by the government of Langkat Regency are considered to be precise at the beginning of the implementation of the formation of important instruments in the success of the child friendly city program, among others, by the formation of child friendly city task force team of Langkat Regency, District Children's Forum up to the sub-district level, and Village Appointment and Determination / Sub district Who Developed Village / Village Eligible Children in Langkat.has District made in the year 2013 Langkat regency government awarded District Eligible Son Pratama. A remarkable achievement in the early years of child friendly city policy implementation.

However, one year later the Langkat Regency Government was unable to maintain its performance. this is because the commitment is not optimal from the child friendly city task force team, so the PPKB and PPA offices are difficult to move. However, in 2014 until now the Office of PPKB and PPA continue to make new breakthroughs that child friendly city task force team can be more coordinated and can apply the child friendly city policy optimally. Related to the problematic of children in Langkat Regency handling is considered not optimal. In relation to street children, although there are already social workers (social workers) but still there are street children in Langkat Regency who work as a beggar.related to the victims of violence also in Langkat District is also very high in January-December 2016 alone has reached 131 cases of violence type of physical violence, domestic violence, sexual, trafficking and others. On the basis of that also the researchers see that the high number of cases of violence is also a homework that must be completed by all parties, of course, with cooperation with all elements be it government, apparatus, private and community.

\section{B. Resources}

In relation to the fulfillment of children's rights in Langkat district there are still some weaknesses related to the understanding of human resources to child friendly city Still the founding of village and village leaders whose understanding is still minimal related to child friendly city so that this policy is strong in the district, but becomes weak when implemented at the village and village level. In addition, there are frequent displacements and permutations occurring in the personal environment of an agency, thus it becomes a problem for the child friendly city Langkat taskforce team, from which it becomes the basis for the difficulty of sometimes communication and coordination in the fulfillment of the rights of the child. The inappropriateness of child friendly city-related understanding that occurred in the regional work unit (SKPD) arrangement and the administrative leaders of the kelurahan and village will 
certainly be an impediment to child friendly city policy implementation in Langkat Regency. It is supposed that the Office of PPKB and PPA which is the leading sector of child friendly city is working on all regional work unit (SKPD) and regional leaders from sub-district to village level to understand and apply child friendly city policy in each institution with advocacy and guidance.

In relation to child friendly city policy budgeting in Langkat Regency comes from Langkat District Budget. CSR funds from companies in Langkat Regency cannot be directed to assist programs related to children due to the establishment of the Child Care Companies Association recommended by the Ministry of Women Empowerment and Child Protection of the Republic of Indonesia, so that companies if joining have an obligation to provide his CSR funds for the benefit of children's welfare in Langkat Regency. The District's decent budget policy of 300 million children has been distributed in half to P2TP2A as a government supporting agency in advocating and protecting children. The cost for the child friendly city program is only 57 Million. It is not possible with these minimum costs could advocate 23 sub-districts, 37 subdistricts and 240 villages in Langkat Regency.

Regarding the target of Langkat Regency to become a child-friendly district according to the interview result predicted 5 to 10 years ahead with the notes that the budget is optimal and the community and the business world can be more Berliners in the implementation of child friendly city policy. And that should be an important note for the PPKB and PPA offices should prioritize the program in the subdistrict, kelurahan, and the village because it becomes the basis if you want to say the decent district of children. society Basically, Langkat regency is entitled to become child's worth if its sub-district is suitable for children, just as if the subdistrict has the right to be a child if the village and its village have decent children.

\section{Characteristics of Implementor Agencies}

In relation to the implementing agency or child friendly city policy implementer in Langkat Regency has been established through the Langkat Regency Regent's Decree on the child friendly city Task Force Team. Overall all stakeholders and regional work unit (SKPD) are already incorporated in the child friendly city task force. But in fact, the field only an active, and even then regional work unit (SKPD) which related to basic services. Related to the obstacles experienced by the child friendly city task force team in child friendly city implementation in Langkat regency is not yet comprehensive. Human resources from regional work unit (SKPD) have child friendly city related understanding, making it difficult when the resources are transferred to other agencies to create vacancies despite being replaced with new employees but still it just has to start from scratch again. The problems and obstacles in implementing the child friendly city are not only in the regional work unit (SKPD) but also in the region. For example, the implementation of the decent sub-district policy of the children, of course, the subdistrict leader as the supreme leader in the subdistrict instructed that each village and village can apply the policy in the village and village areas. We know that after the existence of Village Law number 6 of 2014 makes the village autonomous and empowered and make the village has its own budget. So in the application of child friendly city considered easy to synergize the program because of budget availability. But the problem is the area of the urban village that has a limited budget so it will be difficult to implement the policy with the maximum.

\section{Attitude or Trend}

One of the supporting elements of the child friendly city is the availability of a child participation container called the Children's Forum. Forum child itself is a container organization in which there are all elements of children. The presence of children's forums makes children have a container for their aspirations. When the container is available, of course, there is no more reason the government does not know the complaints and wishes of children in Langkat. As a result of previous interviews saying that their demand is channeled though not entirely. However, we must appreciate it.

One of the supporting elements of the child friendly city is the availability of a child participation container called the Children's Forum. Forum child itself is a container organization in which there are all elements of children. The presence of children's forums makes children have a container for their aspirations. When the container is available, of course, there is no more reason the government does not know the complaints and wishes of children in Langkat. As a result of previous interviews saying that their demand is channeled though not entirely. However, we must appreciate it.

the role of deliberation of development plans ((Musrenbang)) itself is also very optimal in the success of child friendly city policy. Langkat Regency Government has also been responsively related to the participation of children in development, by involving children forum in deliberation of development plans (Musrenbang)) that alone has become proof of the seriousness of the government in succeeding child friendly city policy.

BAPPEDA of Langkat Regency as the head of the Langkat District taskforce team has instructed all regional work unit (SKPD) to create activities and programs that touch on mother and child. But the researchers see the performance of BAPPEDA not so dominant in controlling and guarding the implementation of child friendly city policy in each regional work unit (SKPD). So there is an inequality of programs related to child friendly city. From the above statement can be concluded that BAPPEDA itself has a central role in coordinating all regional work unit (SKPD) in Langkat. One indicator of child friendly city policy support is that the Government should have a Decent Regency Action Plan (regional action plans - child friendly city) which is the action plan of each REGIONAL WORK UNIT (SKPD) in applying the district decent child policy. The following is the District Action Plan for Eligible Children (regional action plans -child friendly city) of Langkat Regency. Researchers see only a few regional work unit (SKPD) related to basic services that 
actively participate in the implementation of child friendly city, of course, it is not a good thing. The cooperation that has been agreed through the Langkat Regent's Decree related Team taskforce has been properly must be accounted for. The assertiveness and reward of the regional leaders are also expected to have a positive effect in Langkat Regency's worth of children.

\section{E. Organizational Communications and Activity}

Coordination is a powerful mechanism for the implementation of public policy. The better the coordination of communication between the parties involved in an implementation process, then the assumption of mistakes will be very small to happen. And, and vice versa. Coordination of the child friendly city taskforce team of Langkat Regency is currently quite good and the coordination form is also done in several ways such as meeting agenda and communication via mobile cellular. This is done as an effort if there are problems related to the protection and welfare of children and women they can immediately coordinate and take appropriate and responsive steps. Meetings are conducted with a ratio of 3 months, the agenda of the meeting held at the office of the Office of PPKB and PPA and can also be done at BAPPEDA Langkat.

From the previous interviews, the researcher found that in the beginning of 2012 and 2013 the coordination was very poor, so that was one of the reasons why child friendly city's award failed to get Langkat Regency back. But it has become a separate evaluation by the Government of Langkat. So from 2014 until now, the coordination is done very well, evidenced by the agenda of regular meetings, activities that are followed by child friendly city taskforce team members, child friendly city socialization, and other agendas that support the application of decent district children.

Related to the social condition of the community is still found the people who do not know the information about the policy of Decent of Children District. Although sometimes the policies they do have decent children. For example, when the village verification team of village eligible to visit one of the villages in the sub-district of Bahorok, they did not understand the concept of village worthy of the children, but the program they implemented has already entered the child-worth indicators such as changing the fence in the village office from formerly pointed iron into ordinary cement so as not to harm the child The village head instructed parents to make maghrib movements. Provide playground and time of expression of the child in the occultation of the village.

From the results of previous interviews, it was found that in fact the programs and policies related to the village and village proper for the children have been done by the community in Langkat Regency even though they have not been well understood related to the village and village proper policies. The village or eligible village must meet the standard of the assessment indicated that is prescribed by the Ministry of Women Empowerment and Child Protection of the Republic of Indonesia.The PPKB and PPA offices also feel that the child-friendly district programs and policies are responded well by the public at large, as they are related to the protection and welfare of their children as well.

Basically, high public awareness will facilitate the performance of the government in realizing decent district children. The child friendly city policy will also not be implemented properly without any interference from the business world.The Ministry of Women's Empowerment and the Child Protection Republic of Indonesia instructed the companies to unite and form the Association of child care companies and to participate in the success of child-related programs. But until now these instructions cannot be implemented because the Government itself is not optimal in coordinating to the company or business world in Langkat District. It should be the power of this business world is used for the benefit of the child.

The child friendly city policy will also not be implemented properly without any interference from political elites. The existence of the role of the political elite gives ease in applying the child friendly city policy, as it relates to the making of regulations and budgeting. Based on the results of previous interviews said that the number of Langkat District Council members amounted to 50 people, then who committed to defending the interests of children only 2 people. From this, it can be interpreted that the understanding of child friendly city has not been evenly distributed in the ranks of Langkat District Legislators so that ignorance becomes ignorance. The homework of the PPKB and PPA Offices in addition to advocating for the community, and the business world should also advocate for the legislative, executive and judicial ranks. In order for the work to be optimal, there must be cooperation with the child friendly city task force team that has become the child friendly city facilitator.

\section{CONCLUSION}

The Decent Regency / City Development Policy (child friendly city) is Indonesia's participation in the world's commitment to creating a Children's Worthy World. The decent districts/municipalities are an elaboration of the international agreement on the need for a world fit for children based on the UN Convention on the Rights of the Child in 1989. From 2012 until now the development of decent childfriendly district policies is being encouraged in Langkat district, through the Office of PPKB and PPA of Langkat Regency as the leading sector and child friendly city task force team which is mandated by Langkat Regent through its decision letter. This is the basis for the child friendly city policy in the District

In relation to the fulfillment of children's rights in Langkat district there are still some weaknesses related to the understanding of the human resources to child friendly city Still the founding of village and village leaders whose understanding is still minimal related to child friendly city so that this policy is strong in the district, but becomes weak when implemented at the village and village level. Moreover, there is often a movement and permutation that occurred in the staffing environment of an agency so that it becomes a problem for the child friendly city Task Force team Langkat 
Regarding child friendly city policy budgeting in Langkat District comes from Langkat district budget worth 300 million rupiahs. CSR funds from companies in Langkat Regency cannot be directed to help programs related to children. Regarding the target of Langkat Regency to be a child-friendly district according to the interview result predicted 5 to 10 years ahead with the notes that the budget is optimal and the community and the business world can be more Berliners in the implementation of child friendly city policy.

In relation to the implementing agency or child friendly city policy implementer in Langkat Regency has been established through the Langkat Regency Regent's Decree on the child friendly city Task Force Team. Overall all stakeholders and regional work unit (SKPD) are already incorporated in the child friendly city task force. But in fact, the field only in part active, and even then regional work unit (SKPD) which related with basic services. Related to the obstacles experienced by the child friendly city task force team in child friendly city implementation in Langkat regency is not yet comprehensive. Human resources from regional work unit (SKPD) have child friendly city related understanding, making it difficult when the resources are transferred to other agencies to create vacancies despite being replaced with new employees but still it just has to start from scratch again.

Coordination of the child friendly city taskforce team of Langkat Regency is currently quite good and the coordination form is also done in several ways such as meeting agenda and communication via mobile cellular. This is done as an effort if there are problems related to the protection and welfare of children and women they can immediately coordinate and take appropriate and responsive steps. Related to the social condition of the community is still found the people who do not know the information about the policy of Decent of Children District. Although sometimes the policies they do have decent children.
The Ministry of Women's Empowerment and the Child Protection Republic of Indonesia instructed the companies to unite and form the Association of child care companies and to participate in the success of child-related programs. But until now these instructions cannot be implemented because the Government itself is not optimal in coordinating to the company or business world in Langkat District. It should be the power of this business world is used for the benefit of the child.

The child friendly city policy will also not be implemented properly without any interference from political elites. The existence of the role of the political elite gives ease in applying the child friendly city policy, as it relates to the making of regulations and budgeting. Based on the results of previous interviews said that the number of Langkat District Council members amounted to 50 people, then who committed to defending the interests of children only 2 people.

\section{References}

[1] Sofian,Efendi \& Tukiran, 2012, "Metode Penelitian Survei," LP3ES, Jakarta.

[2] Arikunto, Suharsimi.,1996, "Prosedur Penelitian Suatu Pendekatan Praktik," Rineka Cipta, Jakarta.

[3] Agustino, Leo., 2008, "Dasar-Dasar Kebijakan Publik," CV Alfabeta, Bandung.

[4] Dunn, William N., 2003, "Pengantar Analisi Kebijakan Publik Edisi Kedua," Gadjah Mada University Press, Yogyakarta.

[5] Sugiyono., 2012, "Metode Penelitian Kuantitatif Kualitatif,“ CVAlfabeta ,Bandung

[6] A.G,Subarsono., 2008, “Analisis Kebijakan Publik," Pustaka Pelajar ,Yogyakarta.

[7] Kementerian Pemberdayaan Perempuan dan Perlindungan Anak, 2012, "Buku Saku Pengembangan Kabupaten/Kota Layak Anak (CHILD FRIENDLY CITY)," Jakarta. 